\title{
Funds should be appropriated now for agricultural productivity research
}

Adding the agriculture productivity subtitle to Title 14 of the 1985 Food Security Act was a legislative breakthrough made possible by broad Congressional interest and support. The inclusion of Subtitle $\mathrm{C}$ in the research section gave alternative agriculture the official recognition and credibility that comes with being written into a major multi-year farm bill.

This action was especially significant because it was the first taken by Congress to implement USDA's 1980 report and recommendations on organic farming. This widely-circulated report concluded that research and education programs should be developed and implemented to address the needs and problems of organic farmers and to enhance the success of conventional farmers who may wish to shift toward organic farming systems and technologies.

Unfortunately this balanced and constructive report had little impact on official USDA policy. It has, however, had considerable influence in changing attitudes in other public agencies and institutions, including many land grant universities. It gave much-needed scientific and economic credibility to organic farming, which was described recently in an Office of Technology Assessment report as an important emerging agricultural technology.

This legislation, guided by James Weaver (D-OR) in the House and Patrick Leahy (D-VT) in the Senate, also won over the agricultural establishment in Congress. Chairman Kika de la Garza (D-TX) of the House Agriculture Committee has called it "a very small first step to bring coordination to an area that hopefully can be the salvation of American and world agriculture in the years to come." The first time the legislation passed the House, he told its members in remarks on the floor that they would "not have a more important bill on agriculture this year."

By 1985 the proposal had gained so much ground that it passed without a roll call. Four national farm organizations were pushing it by that time, most urban representatives supported it, and it had the attention and backing of a long list of national environmental, church, and consumer groups. Subtitle $\mathrm{C}$ has all the earmarks of an idea whose time has come.

\section{Budget problem encountered}

Unfortunately this legislation became law at a time of severe budget restraint. Although the funding needed for agriculture productivity research and education activities is authorized, there is no assurance that the $\$ 2$ million that has been requested by Congressional supporters to get USDA started on these programs will actually be appropriated. All new legislative initiatives have rough going due to the continuing bud- get crunch and that appears to be the prognosis for Subtitle $\mathrm{C}$ at this time.

We believe Congress should set budget considerations aside and make an exception in regard to implementing the productivity provisions of the farm bill. It is an extremely costeffective way to do something about high input costs and related economic problems in agriculture. The amount of money involved is extremely small and the need to initiate a modest research and education effort is at least six years overdue.

According to the scientists who wrote the 1980 USDA report, "much can be learned from a holistic research effort to investigate the organic system of farming, its mechanisms, interactions, principles, and potential benefits to agriculture both at home and abroad." The report further stressed that a complete understanding of these low-input systems of production would require a long-term, coordinated, interdisciplinary program. Subtitle $\mathrm{C}$ was designed with these specific objectives in mind.

\section{Farm costs reduced}

Agriculture and farm structure trends over the past six years have only served to underscore the critically important nature of such an effort. The urgent need to cut farm production costs alone justifies full funding for Subtitle $\mathrm{C}$. It is imperative that all farming systems be investigated that can turn a profit for the individual farmer while simultaneously reducing huge government subsidy payments. The legumebased cropping systems and other technologies characteristic of organic farms may help point the way toward achieving a measure of both economic and environmental stability in agriculture. Given the growing problems that continue to plague conventional, chemical-intensive agriculture, shouldn't our agricultural research and education institutions now be initiating long-term studies of alternative systems and their potential for restoring balance, profits, and sustainability to agriculture?

At the very least, funding should be provided for the preliminary non-research provisions of the legislation. That includes a detailed and comprehensive information study to inventory and classify all relevant studies related to agriculture productivity and establishment of the panel of public experts who would make decisions about appropriate research projects.

If that preliminary work could be completed during the coming year, it would be much easier to push ahead with specific on-farm research projects that are the most important aspects of the authorized agriculture productivity activities. 